\title{
East Syrian Networks in Constantinople: Mar Aba, Paul the Persian, and the Sleepless Monks
}

\section{DANIEL OLTEAN}

Mar Aba and Paul the Persian, two theologians from Persia, traveled to and lived in Constantinople in the first half of the sixth century. During their journey and stay, they used and were supported by an East Syrian network already existing in the capital. The present study focuses on the Sleepless monks, one of the key elements of this network, and their connections with Syrian, Greek, and Latin worlds, including Leontius of Byzantium and Cassiodorus.

\section{INTRODUCTION}

The journeys of theologians, ascetics, and monks from Persia to the Roman world before the Arab conquest are often mentioned in the East Syrian sources. Pilgrimages, education, and religious debates were among the main reasons for these travels, while Jerusalem and the Holy Land, ${ }^{1}$

An earlier version of this paper was presented at the conference "Migration and Mobility across the Roman-Persian Frontier, 3rd-7th c. A.D.," organized by Ekaterina Nechaeva and Alexander Sarantis at the University of Tübingen in December 2018. I am grateful to the organizers of and participants in this conference for valuable input and discussions. Special thanks to anonymous reviewers of the Journal of Early Christian Studies for their comments, suggestions, and corrections, which have helped me improve this article.

1. See Otto F. A. Meinardus, "The Nestorians in Egypt: A Note on the Nestorians in Jerusalem," OrChr 51 (1967): 112-29, here 123-29; Jean-Maurice Fiey, "Le pèlerinage des Nestoriens et Jacobites à Jérusalem," Cahiers de Civilisation Medievale, Xe-XIIe siècles 12.2 (1969): 113-26; Sebastian P. Brock, "Syriac into Greek at Mar Saba: The Translation of St. Isaac the Syrian," in The Sabaite Heritage in the Orthodox Church from the Fifth Century to the Present, ed. Joseph Patrich, Orientalia Lovaniensia Analecta 98 (Leuven: Peeters, 2001), 201-8; Sabino Chialà, "Monaci 
Alexandria and the Egyptian desert, ${ }^{2}$ as well as Edessa and Constantinople, seem to have become the privileged destinations. Sometimes East Syrian monks established communities far from their own homes. More often they returned to Persia with this significant foreign experience.

Obviously, the pilgrimage to Jerusalem and other sacred places was sometimes only a legendary topos. Fortunately, we also benefit from Greek and Latin sources that confirm the presence of East Syrians in the Roman Empire. Among these Easterns, this article focuses on two of the best known: Mar Aba and Paul the Persian.

Future catholicos of the Church of the East (540-52), Mar Aba traveled between 525 and 533 to Edessa, Alexandria, Athens, Corinth, Constantinople, and Antioch. ${ }^{3}$ His Life, written in the late sixth century by one of his disciples, ${ }^{4}$ describes this journey as a pilgrimage, as formative travel, and as apostolic and missionary work among heretics and pagans. A contemporary Greek source written by Cosmas Indicopleustes, an Alexandrian merchant and scholar, confirms this travel. In his Christian Topography, written between 547 and 549, Cosmas Indicopleustes mentioned that Mar Aba, there named Patrikios, "man of God and excellent master," came "from the land of the Chaldeans to complete the mission of Abraham" 5

siro-orientali in Palestina: Echi della riforma di Abramo di Kashkar," in Knowledge and Wisdom: Archeological and Historical Essays in Honour of Leah Di Segni, ed. Giovanni C. Bottini, Lesław D. Chrupcała, and Joseph Patrich (Milan: Edizioni Terra Santa, 2014), 215-35.

2. See Meinardus, "The Nestorians in Egypt," 112-22; Jean-Maurice Fiey, "Coptes et Syriaques, contacts et échanges," Studia Orientalia Christiana, Collectanea 15 (1972-73): 295-365; Florence Jullien, “Types et topiques de l'Égypte: Réinterpréter les modèles aux VIe-VIIe siècles," in Monachismes d'Orient: Images, échanges, influences, Hommage à Antoine Guillaumont, ed. Florence Jullien and Marie-Joseph Pierre, Bibliothèque de l'École des Hautes Études, Sciences Religieuses 148 (Turnhout: Brepols, 2011), 151-63.

3. Life of Mar Aba (hereafter V. Aba) 6-10 (ed. and trans. Florence Jullien, Histoire de Mār Abba, catholicos de l'Orient: Martyres de Mār Grigor, général en chef du roi Khusro Ier et de Mār Yazd-panāh, juge et gouverneur, CSCO [Leuven: Peeters, 2015] 658:1-41, here CSCO 658:9-12; trans. CSCO [Leuven: Peeters, 2015], 659:3-43, here 659:10-14). On Mar Aba see also Paul Peeters, "Observations sur la vie syriaque de Mar Aba, catholicos de l'Église perse (540-552)," in Miscellanea Giovanni Mercati, ST 125 (Vatican: Biblioteca Apostolica Vaticana, 1946), 5:69-112; Wanda Wolska, La Topographie chrétienne de Cosmas Indicopeustès: Théologie et science au VIe siècle, Bibliothèque byzantine, Études 3 (Paris: Presses Universitaires de France, 1962), 63-73.

4. Cf. Florence Jullien, "Introduction," in V. Aba, CSCO 659:xix-xxiii.

5. Cosm. Ind. Top. 2.2 (ed. and trans. Wanda Wolska-Conus, Cosmas Indicopleustès, Topographie chrétienne, 3 vols., SC 141, 159, and 197 [Paris: Éditions du Cerf, 1968-73], here SC 141:306-7); 8.25 (SC 197:194-95). On Cosmas Indicopleustes 
in the companionship of his teacher and friend Thomas of Edessa. ${ }^{6}$ Converted by the instruction of Mar Aba in Alexandria, Cosmas, originally from Antioch, ${ }^{7}$ became a disciple of the doctrine improperly known as "Nestorian."

The case of Paul the Persian is more complex, because the sources mention this name in connection with four persons from the sixth century who may or may not be the same person. Despite this ambiguity, it is generally accepted that the Constantinopolitan Paul the Persian was a renowned theologian educated at the School of Nisibis, who participated in a public debate between Christians and Manicheans in 527 and played an important role in the religious formation of Junillus Africanus, chief legal minister (quaestor) from 542 to $549 .{ }^{8}$

Practical aspects of Aba's long journey and Paul the Persian's stay in Constantinople raise several questions, especially concerning their required network of friends, acquaintances, co-religionaries, or co-nationals living in the Roman Empire. This network was arguably more developed in Syria, where the author of Aba's Life places not only Thomas, whom he met in Edessa, but also Sergius, "who had linked the Arian ideas with paganism," and with whom Mar Aba "wanted to dispute and establish the true faith." Concerning Egypt, Wanda Wolska-Conus has already pointed out

see Wolska, La Topographie chrétienne, 1-11; Wanda Wolska-Conus, "Stéphanos d'Athènes et Stéphanos d'Alexandrie: Essai d'identification et de biographie," in REB 47 (1989): 5-89, here 28-30. For the identification of Patrikios with Mar Aba see V. Aba, prologue (CSCO 658:5; trans. CSCO 659:5); cf. Peeters, "Observations," 71-72 and 79-80.

6. See also V. Aba 7 (CSCO 658:9; trans. CSCO 659:10). On Thomas of Edessa see Peeters, "Observations," 77-80; Wolska, La Topographie chrétienne, 73-81; Paolo Bettiolo, "Scuola ed economia divina nella catechesi della chiesa di Persia: Appunti su un testo di Tommaso di Edessa ( $†$ ca 542)," in Esegesi e catechesi nei Padri (secc. IV-VII), ed. Sergio Felici, Biblioteca di scienze religiose 112 (Rome: Libreria Ateneo Salesiano, 1994), 147-57.

7. Géographie de Moïse de Corène d'après Prolémée, trans. Arsène Soukry (Venice: Imprimerie Arménienne, 1881), 5-7.

8. On Paul the Persian, see Giovanni Mercati, "Per la vita e gli scritti di 'Paolo il Persiano': Appunti da una disputa di religione sotto Giustino e Giustiniano," in Note di letteratura biblica e cristiana antica, ST 5 (Rome: Tipografia Vaticana, 1901), 180-206; Wolska, La Topographie chrétienne, 66-68; Antoine Guillaumont, "Justinien et l'Église de Perse," in DOP 23-24 (1969-70): 39-66, here 46-48; Dimitri Gutas, "Paul the Persian on the Classification of the Parts of Aristotle's Philosophy: A Milestone between Alexandria and Bagdâd," in Der Islam-Zeitschrift fur Geschichte und Kultur des Islamischen Orients 60.2 (1983): 231-67, here 238-39n14.

9. V. Aba 6 (CSCO 658:9; trans. CSCO 659:10). This Sergius is generally identified with the famous priest, physician, and translator Sergius of Reshaina (d. 536). 
that Cosmas was not the only "Nestorian" in sixth-century Alexandria. ${ }^{10}$ Rather, it seems that Cosmas belonged to an intellectual elite that focused on the theological, philosophical, and cosmological queries of the time. This non-Chalcedonian Dyophysite group of Alexandria-close to theological debates, but also to liturgical life ${ }^{11}$ —organized as an ecclesiastical and intellectual circle, must be viewed in opposition to another Alexandrian Christian group criticized by Cosmas himself: ${ }^{12}$ that is, a Miaphysite circle led by John the Grammarian or Philoponus (d. 575), the finest exponent of the Alexandrine school of the time.

If these East Syrian networks can be proved in the cases of Edessa and Alexandria, the situation remains more obscure for Constantinople. We have no direct information about the milieu where Mar Aba and Paul the Persian lived, nor the friends who could have supported them. However, Greek and Syriac-connected texts can be read together in order to identify some elements of Mar Aba's visit to Constantinople. In a similar way, Latin sources help reconstruct the intellectual circle of Paul the Persian. In this context, the present research focuses on the following two objectives.

First, we will show that Mar Aba's visit to Constantinople included the monastery of the Akoimetai (the Sleepless monks), one of the most famous in the capital, kr $\mathrm{m}$ for its links with the Syrian world. In the library of this monastery ar Aba and Thomas of Edessa found some Greek texts which they translated into Syriac after their return to Persia. This unexpected connection will be proved using a treatise by Leontius of Byzantium, who criticized the Sleepless ones for their "Nestorian" views.

Second, we will underline that Paul the Persian's pupils were educated in a school organized in connection with the same monastery of the Akoime-

See Peeters, “Observations," 77; Wolska, La Topographie chrétienne, 71-72; Henri Hugonnard-Roche, "Note sur Sergius de Rešainā, traducteur du grec en syriaque et commentateur d'Aristote," in The Ancient Tradition in Christian and Islamic Hellenism: Studies on the Transmission of Greek Philosophy and Sciences Dedicated to H. J. Drossaart Lulofs on His Ninetieth Birthday, ed. Gerhard Endress and Remke Kruk, Centre of Non-Western Studies Publications 50 (Leiden: Research School CNWS, 1997), 121-43; Emiliano Fiori, "Un intellectuel alexandrin en Mésopotamie: Essai d'une interprétation d'ensemble de l'œuvre de Sergius de Rēš'aynā," in De l'Antiquité tardive au Moyen Âge: Études de logique aristotélicienne et de philosophie grecque, syriaque, arabe et latine offertes à Henri Hugonnard-Roche, ed. Elisa Coda and Cecilia Martini Bonadeo, Études musulmanes 44 (Paris: Vrin, 2014), 59-90.

10. Wolska, La Topographie chrétienne, 147-51.

11. Cosm. Ind. Top. 7.97 (SC 197:164-67). See Erik Peterson, “Die alexandrinische Liturgie bei Kosmas Indikopleustes," in Ephemerides liturgicae 46 (1932): 66-74; Sameh F. Soliman, "The Allusions to the Alexandrian Liturgy in the Christian Topography of Cosmas Indicopleustes: The Coptic Texts," in OCP 83.2 (2017): 491-98.

12. Cosm. Ind. Top. 1.1-4 (SC 141:272-77). 
tai. In this monastic milieu, Paul the Persian found the chance to pursue the educational process he had begun, in other conditions, at Nisibis. Furthermore, Paul's school served as a model for Cassiodorus when he planned his monastery at Vivarium, in Southern Italy.

These two objectives will be pursued independently, to keep the internal coherence of the article. The results will offer a more accurate perception of the East Syrian networks in sixth-century Constantinople, allow understanding of their links with the monks of the Roman world in this period, and underline the contacts between the Akoimetai and some well-known theologians of this period like Leontius of Byzantium and Cassiodorus.

\section{MAR ABA AND THE SLEEPLESS MONKS}

The travel of Mar Aba and Thomas of Edessa to Constantinople ${ }^{13}$ and the subsequent return of Thomas, who remained there until his death, ${ }^{14}$ support the idea that some "Nestorian" links existing in the capital were similar to those mentioned in Alexandria. To clarify these connections the key point is the Church of the East's tradition regarding Mar Aba's translation into Syriac of Theodore of Mopsuestia's anaphora.

According to the Chronicle of Seert, during their stay in Alexandria, Mar Aba and Thomas of Edessa "gathered the books of Theodore the Interpreter." ${ }^{15}$ Evidently, this was one of the goals of their journey. Furthermore, the East Syrian liturgical tradition considers Mar Aba the translator of both Theodore and Nestorius's liturgies. Some Syriac manuscripts from the sixteenth and seventeenth centuries mention that:

We begin to write the Hallowing of Mar Theodore the Interpreter of the Holy Scriptures, Bishop of Mopsuestia, which Mar Aba the catholicos rendered and translated from Greek into Syriac when he went up to Constantinople. And he brought it out with him with the help of Mar Thomas of Edessa the teacher. ${ }^{16}$

13. V. Aba 9 (CSCO 658:12; trans. CSCO 659:12).

14. Cosm. Ind. Top. 2.2 (SC 141:306-7).

15. Chronicle of Seert (hereafter Chr. Seert) 2.27 (ed. and trans. A. Scher, Histoire nestorienne inédite [Chronique de Séert], PO 4:211-313; 5:217-344; 7:95-203; 13:433-639, here PO 7:155-56).

16. Manchester, John Rylands University Library syr. 19 (1604 C.E.), f. 31v, cf. Anthony Gelston, "The Origin of the Anaphora of Nestorius: Greek or Syriac?," in Bulletin of the John Rylands Library 78.3 (1996): 73-86, here 73-74. A similar mention in London, British Library Add. 7181 (1570 c.e.), f. 47v, cf. Catalogus codicum manuscriptorum orientalium qui in Museo Britannico asservantur, Vol. 1: Codices syriacos et carshunicos amplectens, ed. Josiah Forshall and Friedrich A. Rosen 
There is no evidence that Mar Aba himself translated these texts and it is more reasonable to assume that after his return from Constantinople, he gathered around him a team of teachers and translators, among whom we find obviously Thomas of Edessa, but also Simeon bar Tabbahe of Edessa, Cyrus of Edessa, ${ }^{17}$ and the translator of Nestorius's Liber Heraclidis. ${ }^{18}$

While the contemporary East Syrian sources contain isolated references to some liturgical prayers borrowed from Theodore, ${ }^{19}$ there is only one Greek text that mentions the use of Theodore's anaphora in Byzantium. ${ }^{20}$ The information is given by Leontius of Byzantium (d. after 544) ${ }^{21}$ in his

(London: British Museum, 1838), 59a. On the translation of Nestorius's anaphora see Manchester, John Rylands University Library syr. 19, f. 42v: Mar Aba the great catholicos of blessed memory, when he went into the Roman Empire, rendered the Anaphora of Mar Nestorius and all his writings from Greek into Syriac, cf. Gelston, “The Origin," 73. See also James F. Coakley, "A Catalogue of the Syriac Manuscripts in the John Rylands Library," in Bulletin of the John Rylands Library of Manchester 75.2 (1993): 105-208, here 140-41.

17. Cf. William F. Macomber, "Introduction," in Six Explanations of the Liturgical Feasts by Cyrus of Edessa, an East Syrian Theologian of the Mid-Sixth Century, 2 vols., CSCO 355-56 (Leuven: Peeters, 1974), here CSCO 356:xii and n51.

18. Cf. Nestorius, Le livre d'Heraclide de Damas, preface (trans. François Nau [Paris: Letouzy et Ane, 1910], 1 and n8). See also Luise Abramowski, Untersuchungen zum Liber Heraclidis des Nestorius, CSCO 242 (Leuven: Peeters, 1963), 7-13.

19. Narsai, Homilies 17: "An Exposition of the Mysteries" (trans. Richard H. Connolly, The Liturgical Homilies of Narsai [Cambridge: The University Press, 1909], 1-33, here 16-17); Cyrus of Edessa, Explanation of the Pascha 5.10 (ed. and trans. Macomber, Six Explanations, CSCO 355:57-58; trans. CSCO 356:49-50 and n3).

20. See Jacob Vadakkel, The East Syrian Anaphora of Mar Theodore of Mopsuestia: A Critical Edition, English Translation and Study (Kottayam: Oriental Institute of Religious Studies India Publications, 1989), 77; Pierre Yousif, "The Anaphora of Mar

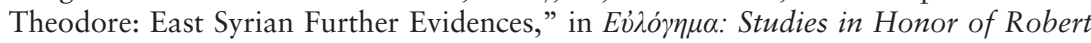
Taft, SJ, ed. Ephrem Carr et al., Studia Anselmiana 110 (Rome: Pontificio Ateneo S. Anselmo, 1993), 571-91.

21. On Leontius of Byzantium see Marcel Richard, "Léonce de Jérusalem et Léonce de Byzance," Mélanges de Science Religieuse 1 (1944): 35-88; David B. Evans, Leontius of Byzantium: An Origenist Christology, DOS 13 (Washington: Dumbarton Oaks Center for Byzantine Studies, 1970), 147-85; John J. Lynch, "Leontius of Byzantium: A Cyrillan Christology," in TS 36 (1975): 455-71; Lorenzo Perrone, La Chiesa di Palestina e le controversie cristologiche: Dal concilio di Efeso (431) al secondo concilio di Costantinopoli (553), Testi e ricerche di scienze religiose 18 (Brescia: Paideia, 1980), 190-94 and 260-85; Alois Grillmeier and Theresia Hainthaler, Christ in Christian Tradition 2.2: The Church of Constantinople in the Sixth Century, trans. John Cawte and Pauline Allen (Louisville, KY: Westminster John Knox Press, 1995), 181-86; Brian E. Daley, "Introduction," in Leontius of Byzantium, Complete Works, OECT (Oxford: Oxford University Press, 2017), 24-25. See also a summary of research on Leontius of Byzantium in Carlo Dell'Osso, Il calcedonismo Leonzio di Bisanzio (Rome: Edizioni Vivere, 2003), 153-75. 
treatise Against the Nestorians, written in Constantinople in the context of Emperor Justinian's edict against the Three Chapters (543/544), or even before, in the $530 \mathrm{~s},{ }^{22}$ maybe just a few years after Aba's visit. In this treatise, one of Leontius's most virulent criticisms was directed towards Theodore of Mopsuestia and the introduction of a new anaphora:

He has improvised a Eucharistic prayer, different from the one handed down to the churches from the fathers, neither respecting the anaphora of the Apostles nor considering that of the great Basil, which is written in the same Spirit, as worthy of account. With this anaphora of blasphemies (not of prayers, after all!), he has carried out the sacraments of initiation..$^{23}$

This remarkable connection between Greek and Syriac sources shows that Mar Aba and Thomas of Edessa were in direct contact with the "Nestorians" criticized by Leontius. But who were these "Nestorians"? Writing about these heretics, Leontius revealed that in his youth, he was one among them. While modern research has focused on identifying (or not) the Chalcedonian theologian Leontius (of Byzantium) with the Palestinian Origenist monk Leontius, little attention has been paid to those first years of Leontius of Byzantium's career. It is generally assumed that in all likelihood he became a monk in Palestine in the early sixth century. Previously, he had received theological training in Constantinople among some Christians who declared their adherence to Chalcedon, ${ }^{24}$ although in reality, according to Leontius, they followed the teaching of Nestorius and Theodore of Mopsuestia. In Leontius's own words:

There was a time when I myself formed part of their company. They [the Nestorians] captivated both my time and my reason then, young as I was, and they left no instrument of wickedness untried, to achieve this purpose, for I prized accuracy of doctrine, and once I had tasted it with the tip of my finger-as the saying goes-I became avid and omitted nothing that might curb my eagerness. They took hold of me, like a blind man groping after his way, and tried to pull me down into the pit of their own wickedness. ${ }^{25}$

Educated in this "Nestorian" milieu, the young Leontius was enticed by solitary life and left his country for a new one, until divine grace led him into "the hands of godly men." They cleansed his mind by means of the books of "holy and wise men" and taught him the true faith. Now

22. Daley, "Introduction," 32.

23. Leontius of Byzantium, Against the Nestorians (hereafter Leont. B. Nest.) 2 (ed. and trans. Daley, Leontius of Byzantium, Complete Works, 410-523, here 424-25).

24. Leont. B. Nest. 19 (Daley, Complete Works, 416-19).

25. Leont. B. Nest. (Daley, Complete Works, 412-13). 
in the camp of the right Chalcedonians, Leontius returned to Constantinople, where he lived as an urban hermit, perceiving with different eyes the heretical practices of his former companions. About their customs, Leontius writes:

When they [the Nestorians] have taken him [the victim] in hand and made him obedient in the way they wish, if the victim is a monk they turn him towards Greek literature, if he is considered apt for it; and they make much ridicule of the simplicity of monastic life, and urge that fasting and watching and solitude are worth nothing (for they calumniate the life of practical virtue, and are disgusted even with the name of it), and urge him to change his habit, as something which stands in the way of this world's wisdom. ${ }^{26}$

The passage indicates that this Christian circle was in fact a monastic group, since it accepted monks among its members. However, the customs of these monks focused more on the urban way of life than on solitude, while the reference to Greek literature and the world's wisdom is relevant to this aspect. In reality, the monks criticized by Leontius seem to be preoccupied with both theological and secular learning. They lived in the region of Constantinople, where, according to the same Leontius, they guaranteed "access to the emperor and the first rank of magistracies and contact with learned members of their company," 27 and had the power to introduce their adepts into the clergy of the church. ${ }^{28}$ These monks are sufficiently numerous to be divided into two factions: those who "pretend to be in communion with the church" and those who admire Nestorius. ${ }^{29}$ In addition, the Constantinopolitan "Nestorians" translated their books in the language of "the Chaldeans and Armenians," 30 and maintained contact with the "Nestorian" church of Persia:

Your disciple was Barsauma, who led the Persian kingdom astray with teachings of godlessness and the promiscuity of his life, legislating that no member of the clergy, to say nothing of the laity, need abstain from illegitimate sexual union or polygamy; for he held orgies and drinking-bouts to be gifts of God. ${ }^{31}$

In attempting to identify these Constantinopolitan "Nestorian" monks, Marcel Richard and Brian Daley have timidly compared them to the

26. Leont. B. Nest. 4 (Daley, Complete Works, 416-19).

27. Leont. B. Nest. 3 (Daley, Complete Works, 416-17).

28. Leont. B. Nest. 6 (Daley, Complete Works, 418-19).

29. Leont. B. Nest. 6 (Daley, Complete Works, 418-19).

30. Leont. B. Nest. 23 (Daley, Complete Works, 428-29).

31. Leont. B. Nest. 22 (Daley, Complete Works, 426-27). 
Akoimetai. ${ }^{32}$ From a theological perspective, David Evans has argued that some doctrinal thoughts of Leontius's opponents can be found in the Dionysian Corpus. ${ }^{33}$ This opinion was recently used by Istvan Perczel who has also proposed that Pseudo-Dionysius frequented either the circle of the Protoctist/Tetradite Origenist Palestinian monks, ${ }^{34}$ or rather that of the bishop Theodoret of Cyrus. ${ }^{35}$ On the other hand, Daley has underlined that, even if the Origenist background of Leontius's works hasn't been satisfactorily proved, his treatises against Nestorians can be viewed as one of the first reactions of the Constantinopolitan party led by Theodore Askidas and Domitian of Ancyra against the anti-Origenist monks aided by Patriarch Ephrem of Antioch and the Roman deacon Pelagius, future pope. ${ }^{36}$ From our point of view, there is no doubt that the monastery in question was that of the Akoimetai, one of the most powerful in the Constantinople area in the first half of the sixth century. ${ }^{37}$ Several arguments sustain this assertion.

First, the numerous links and mutual influences existing between this monastery and Persia and Roman Syria must be noted. The founder, Alexander the Akoimetos (d. 430), became a monk and spent most of his life in Syria before departing for Constantinople in 425. His first community

32. Marcel Richard, "Léonce de Byzance était-il origéniste?," in REB 5 (1947): 31-66, here 63; Daley, "Introduction," 32 and n190.

33. Evans, Leontius of Byzantium: An Origenist Christology, 24n6; 44-45n56; 146; David B. Evans, "Leontius of Byzantium and Dionysius the Areopagite," in Byzantine Studies/Études byzantines 7.1 (1980): 1-34.

34. István Perczel, "Once Again on Dionysius the Areopagite and Leontius of Byzantium," in Die Dionysius-Rezeption im Mittelalter: Internationales Kolloquium in Sofia vom 8. bis 11. April 1999, ed. Tzotcho Boiadjiev, Georgi Kapriev, and Andreas Speer, Rencontres de Philosophie Médiévale 9 (Turnhout: Brepols, 2000), 41-85, here 44-52 and 83-84.

35. István Perczel, "Pseudo-Dionysius the Areopagite and the Pseudo-Dormition of the Holy Virgin,” in Mus 125.1-2 (2012): 55-97, here 56; István Perczel, “Theodoret of Cyrrhus: The Main Source of Pseudo-Dionysius' Christology?," in Studia Patristica 96: Papers Presented at the Seventeenth International Conference on Patristic Studies held in Oxford, 2015, Vol. 22: The Second Half of the Fourth Century; From the Fifth Century Onwards (Greek Writers); Gregory Palamas' Epistula III, ed. Markus Vinzent (Leuven: Peeters, 2017), 351-75.

36. Brian E. Daley, "The Origenism of Leontius of Byzantium," JTS (n.s.) 27.2 (1976): 333-69, here 365-66; Daley, "Introduction," 44-50.

37. On the monastery of the Akoimetai, located at Irenaion, on the Asiatic shore of the Bosphorus, $20 \mathrm{~km}$ north of the city, see Jules Pargoire, "Acémètes," in DACL 1:307-21; Gilbert Dagron, "Les moines et la ville: Le monachisme à Constantinople jusqu'au Concile de Chalcédoine (451)," in Travaux et Mémoires 4 (1970): 229-76, here 235-37; Rudolph Riedinger, "Akoimeten," in Theologische Realenzyklopädie, 2:148-53; Peter Hatlie, The Monks and Monasteries of Constantinople, ca. 350-750 (Cambridge: Cambridge University Press, 2007), 106-14 and 168-69. 
in Constantinople had a multi-ethnic vocation, gathering together three hundred monks of Roman, Greek, and Syriac origin, ${ }^{38}$ following the pattern of numerous "international" monasteries existing in Syria at this time. ${ }^{39}$ Moreover, at least one Sleepless monastic community is attested in the same period in Persia. According to the Chronicle of Seert, in the first decades of the fifth century, Yabhalāhā, one of the disciples of the great Persian founder Abdā, established a monastery in the region of Nisibis, on the banks of the Tigris, where the monks were divided into three groups so that "the prayer would never be interrupted" and so that the monks would "imitate the angels." 40 The parallel with Alexander the Akoimetos's contemporary community is astonishing and leads to the conclusion that there was a mutual influence between the two founders or that they used a common model. Another famous case is Mari the Persian, a former student at the School of Edessa and the addressee of the well-known letter by Ibas of Edessa, one of the Three Chapters anathematized in 553. According to Michel van Esbroeck, in 433 Mari lived in the monastery of the Akoimetai and before 452 became the abbot of an Akoimete community. In a letter preserved in Arabic, he is mentioned as "priest and abbot" beside Markellos the Akoimetos (d. 484), the third hegoumenos. ${ }^{41}$ In addition, the Life of Markellos's author pointed out that the abbot had received relics of Persian martyrs. ${ }^{42}$ In all likelihood, they came to Constantinople via Syria, where Theodoret of Cyrus also reported their veneration. ${ }^{43}$ The exchange of letters between Theodoret of Cyrus and Markellos in 450 is

38. V. Alex. Acoem. 42 (ed. Emile de Stoop, "Vie d'Alexandre l'Acémète," in PO 6: 658-702, here 695; trans. Daniel Caner, Wandering, Begging Monks: Spiritual Authority and the Promotion of Monasticism in Late Antiquity, The Transformation of the Classical Heritage 33 [Berkeley: University of California Press, 2002], 249-80, here 692).

39. Cf. Olaf Hendriks, "Les premiers monastères internationaux en Syrie," in OrSyr 3 (1959): 165-84.

40. Chr. Seert 1.68 (PO 5:321-22).

41. Michel van Esbroeck, "Une lettre de Dorothée comte de Palestine a Marcel et Mari en 452," in AB 104 (1986): 145-59; Van Esbroeck, "Who is Mari, the Addressee of Ibas' Letter?" in JTS (n.s.) 38.1 (1987): 129-35.

42. Life of Markellos the Akoimetos (hereafter V. Marc. Acoem.) 29 (ed. Gilbert Dagron, "La Vie Ancienne de Marcel l'Acémète," in AB 86 [1968]: 271-321, here 312; trans. Jean-Marie Baguenard, Vies des saints Alexandre, Marcel et Jean Calybite, Spiritualité orientale 47 [Bégrolles-en-Mauges: Abbaye de Bellefontaine, 1988], 149-92, here 181).

43. Thdt. H. rel. 24.2 (ed. and trans. Pierre Canivet and Alice Leroy-Molinghen, Théodoret de Cyr, Histoire des moines de Syrie, 2 vols., SC 234 and 257 [Paris: Éditions du Cerf, 1977-79], here SC 257:140-41). 
also well known, ${ }^{44}$ while some monastic displacements from the East to Constantinople and vice versa are attested by the Life of the same hegoumenos: Sergius, the abbot of a monastery near the Euphrates, arrived in Constantinople to meet Markellos, while a Sleepless monk, Peter, traveled in the region of Edessa where he made known the reputation of the great Constantinopolitan abbot. ${ }^{45}$

Second, the Sleepless ones were well known for their strict Chalcedonian orientation $^{46}$ : they rejected the Henotikon of the emperor Zenon (482), refused communion with the patriarch Acacius, and composed an epistolary corpus that incriminated Peter the Fuller, patriarch of Antioch and former member of the congregation. This attitude drew the accusation of Nestorianism from their enemies. According to Pseudo-Zachariah, the Akoimetai studied with passion the works of Diodore of Tarsus, Theodore of Mopsuestia, and Theodoret of Cyrus, and persisted in Nestorius's commemoration in the diptychs. ${ }^{47}$ However, the conflict was not only an isolated dispute between two groups with different christological opinions: in 533-34, the opposition of the Akoimetai to the Theopaschite formula sustained by Justinian attracted imperial blame and then papal condemnation. ${ }^{48}$

Finally, the monastery was well known for its rich library and the intellectual quality of some of its monks. In the Life of Alexander the Akoimetos, the author notes that the monks "possessed nothing more than the parchments on which they kept the holy Scriptures." ${ }^{49}$ Markellos was a

44. Thdt. Ep. 142-43 (ed. and trans. Yvan Azéma, Théodoret de Cyr, Correspondance, 4 vols., SC 49, 98, 111, and 429 [Paris: Éditions du Cerf, 1955-98], here SC 111:152-59).

45. V. Marc. Acoem. 22-23 (Dagron, "La Vie Ancienne," 304-6; trans. Baguenard, Vies des saints, 171-73).

46. See Grillmeier and Hainthaler, Christ in Christian Tradition, 2.2:252-62.

47. The Chronicle of Pseudo-Zacharias Rhetor (hereafter Ps-Zach. Chr.) 7.7a (ed. Ernest W. Brooks, Historia ecclesiastica Zachariae Rhetori, 2 vols., CSCO 83-84 [Paris: Typographeo Reipublicae, 1919-21], here CSCO 84:39; trans. Robert R. Phoenix and Cornelia B. Horn, Translated Texts for Historians [hereafter TTH] 55 [Liverpool: Liverpool University Press, 2011], 252).

48. In a letter sent to Pope John II, Justinian accused the Akoimetai who, "in the manner of Jews," had adopted "the perfidious doctrines of Nestorius." Consequently, the pope accepted the request of the emperor and condemned the monks, but also encouraged Justinian to abandon his "feelings of indignation" and receive the monks in communion if they change their heretical opinions. Cf. Justn. Cod. 1.1.8. See also John II of Rome, Letter to Senators, in ACO 4.2:206-10.

49. V. Alex. Acoem. 44 (PO 6:693; trans. Caner, Wandering, Begging Monks, 275). 
copyist $^{50}$ and he surely encouraged the activity of the scriptorium. From 564 , Rusticus, ${ }^{51}$ nephew of Pope Vigilius and one of the leaders of resistance against the Three Chapters, gathered from the library of the Akoimetai many documents related to the councils of Ephesus (Synodicon) $)^{52}$ and Chalcedon, ${ }^{53}$ including the lost Tragedia of Irenaeus of Tyre, a friend of Nestorius. In the same library, Rusticus found the collection of 2000 letters by Isidor of Pelusium, ${ }^{54}$ previously studied by Facundus, bishop of Hermiane in North Africa. ${ }^{55}$ Facundus also quotes from several of Theodore of Mopsuestia's lost works (Against the Allegorists, ${ }^{56}$ Against Eunomius, ${ }^{57}$ On the Mysteries, ${ }^{58}$ Against Apollinaris, ${ }^{59}$ etc.), which he probably discovered in the same monastic library, famous even among the Akoimetai's enemies. ${ }^{60}$ Given the high intellectual level of some Akoimetai, Rudolph Riedinger has stated that the Areopagite's corpus, the Erotapokriseis of Pseudo-Caesarius, and the Homilies of Macarius/Symeon all belonged to the milieu of the Sleepless ones. ${ }^{61}$

50. V. Marc. Acoem. 3 (Dagron, "La Vie Ancienne," 289; trans. Baguenard, Vies des saints, 153).

51. On Rusticus see Prosopographie chrétienne du Bas-Empire (hereafter PCBE), Vol. 2: Prosopographie de l'Italie chrétienne (303-604), ed. Charles Pietri and Luce Pietri, 2 vols. (Rome: École française de Rome, 1999-2002), 2:1956-59 (Rusticus 11).

52. ACO 1.3:37.19; ACO 1.3:38.1; ACO 1.3:39.7; ACO 1.3:40.29; ACO 1.3:44.4; ACO 1.3:84.28; ACO 1.3:174.20; ACO 1.3:119.15; ACO 1.3:181.5; ACO 1.4:242.1; ACO 1.4:243.34. Cf. Eduard Schwartz, "Praefatio," in ACO 1.3:xii-xiii.

53. ACO 2.3.1:27.2; ACO 2.3.3:91.16; ACO 2.3.3:98.27.

54. ACO 1.4:25.21-24.

55. Facundus, Def. 2.4.12 (ed. Jean-Marie Clément and Roel Vander Plaetse, Facundi Episcopi Ecclesiae Hermianensis opera omnia, CCL 90A [Turnhout: Brepols, 1974], 59; trans. Anne Fraïsse-Bétoulières, Facundus d'Hermiane, Defense des Trois Chapitres (À Justinien), 4 vols., SC 471, 478, 479, 484, and 499 [Paris: Éditions du Cerf, 2002-6], here SC 471:21).

56. Facundus, Def. 3.6.13-14 (CCL 90A:95-96; trans. SC 478:107).

57. Facundus, Def. 9.3.44 (CCL 90A:281; trans. SC 484:169).

58. Facundus, Def. 3.2.4 (CCL 90A:74-75; trans. SC 478:45).

59. Facundus, Def. 9.4.4-9 (CCL 90A:282-83; trans. SC 484:173-75). According to Luise Abramowski, "Reste von Theodorets Apologie für Diodor und Theodor bei Facundus," in SP 1 (1957): 61-69 (= TU 63), one of the sources used by Facundus to cite Theodore of Mopsuestia was the florilegium composed by Theodoret of Cyrus in 438 in reply to Cyril of Alexandria's work Against Diodore and Theodore. Her opinion has been refuted by Aimé Solignac, "Un auteur trop peu connu: Facundus d'Hermiane," in Revue d'Études Augustiniennes et Patristiques 51 (2005): 357-74, here 365-66.

60. Ps-Zach. Chr. 7.7b (CSCO 84:39; trans. TTH 55:252).

61. Utto Riedinger, "Pseudo-Dionysios Areopagites, Pseudo-Kaisarios und die Akoimeten," in ByzZ 52.2 (1959): 276-96; Riedinger, "Akoimeten," 149-52. On this topic see Alois Grillmeier and Theresia Hainthaler, Christ in Christian Tradition 2.3: 
All these arguments align with Leontius of Byzantium's description. In fact, in the first decades of the sixth century, the only documented monastery in Constantinople that simultaneously maintained links with Christians from Persia, preserved in its library books of authors belonging to the Antiochian theological school, kept the Chalcedonian line, was accused of Nestorianism, had some links with the Roman delegates, and vigorously intervened in ecclesiastical and political matters was the monastery of the Akoimetai. This rapprochement reasonably solves some unclear aspects of Leontius's treatise and life. In the monastic milieu of the Sleepless ones, Leontius had received his first theological formation. And to return to our purpose, in that same monastery Mar Aba and Thomas of Edessa found the anaphora of Theodore and later translated it into Syriac. The Akoimete community must therefore be viewed as a meeting point between the Greek, Syrian, and Roman worlds. In the sixth century it served as a landmark for eastern travelers to the West.

\section{PAUL THE PERSIAN AND THE SLEEPLESS MONKS}

The second case discussed here is Paul the Persian. According to contemporary Greek and Latin sources, he was implied in both theological debates and sacred learning. Unfortunately, there isn't relevant information about the confessional affiliation of Paul the Persian nor his activity in Constantinople. The dispute between Paul and the Manichean leader Photeinos, ${ }^{62}$ organized by Justin and Justinian as part of their persecution of Manicheans, contains no obvious traces of Paul's christological convictions. However, Giovanni Mercati has observed that Theodore of Mopsuestia had some influence on Paul's thought. ${ }^{63}$ On the other hand, according to Junillus Africanus, Paul the Persian was a teacher, one of the men who "burned with a passion for understanding the divine books." Paul was educated at Nisibis, where "the divine law is taught in a disciplined and orderly fashion by public teachers." Junillus had read a book entitled Rules, used by Paul to "introduce his students to the preliminary, literary meaning of the divine Scriptures before he exposed them to more serious explanations." This book was translated and adapted by Junillus and put in the hands of the African bishop Primasius of Hadrumeta in 542 for use by Christian

The Churches of Jerusalem and Antioch from 451 to 600, trans. Marianne Ehrhardt (Oxford: Oxford University Press, 2013), 289-90.

62. Disp. Phot. (PG 88:529-78).

63. Mercati, "Per la vita e gli scritti," 193-98. 
students. Junillus also translated another "exceptional contribution" of Paul the Persian: a sermon on the Epistle of Paul to the Romans. ${ }^{64}$

There is no other evidence about the size and activity of Paul's school. It seems that after commencing didactic activity in Nisibis, he pursued it in Constantinople, either in a small circle of students, according to the custom of the time, or in an ecclesiastical institution. Once again, as in the case of the dispute with the Manicheans, Theodore of Mopsuestia's influence on Junillus's Instituta is not evident. However, Adam Becker has recently proposed replacing the word "influence" with "subtle connection" to describe the links between the two authors correctly. ${ }^{65}$

Junillus Africanus was not alone in the 540s in his knowledge of Paul the Persian's school. One of the readers of Junillus's Instituta ${ }^{66}$ was Cassiodorus, who resided in Constantinople for a long period, probably from 540 to $554 .{ }^{67}$ In his work entitled Institutiones divinarum et saecularium litterarum, Cassiodorus recommended Junillus's book as an important introductory manual to divine Scripture and manifested interest in imitating the School of Nisibis's model, ${ }^{68}$ in order to organize his monastery school in Vivarium. His main source of information on Nisibis's school evidently was Junillus, and maybe Paul the Persian. Preoccupied with the idea of unifying secular and divine learning, Junillus and Cassiodorus participated in the intellectual life of the same Constantinopolitan circle.

64. Iunil. Inst. preface (ed. Heinrich Kihn, trans. Michael Maas, in Michael Maas, Exegesis and Empire in the Early Byzantine Mediterranean: Junillus Africanus and the Instituta Regularia Divinae Legis, Studies and Texts in Antiquity and Christianity 17 [Tübingen: Mohr Siebeck, 2003], 118-234, here 118-23). See also Maas, Exegesis and Empire, 83 and 113-15.

65. Adam Becker, "The Dynamic Reception of Theodore of Mopsuestia in the Sixth Century: Greek, Syriac, and Latin," in Greek Literature in Late Antiquity: Dynamism, Didacticism, Classicism, ed. Scott F. Johnson (Aldershot: Ashgate, 2006), 29-47. On this topic see also Robert Devreese, Essai sur Théodore de Mopsueste, ST 141 (Vatican: Biblioteca Apostolica Vaticana, 1948), 274-77; Arthur Vööbus, History of the School of Nisibis, CSCO 266 (Leuven: Peeters, 1965), 179-87; Maas, Exegesis and Empire, 13-18.

66. Cass. Div. litt. 1.10.1 (ed. Roger A. B. Mynors, Cassiodori Senatoris Institutiones [Oxford: Clarendon Press, 1937], 34; trans. James W. Halporn, Cassiodorus, Institutions of Divine and Secular Learning and On the Soul, TTH 42 [Liverpool: Liverpool University Press, 2004], 103-233, here 133).

67. On Cassiodorus see James J. O’Donnell, Cassiodorus (Berkeley: University of California Press, 1979); PCBE 2:403-9 (Cassiodorus 2).

68. Cass. Div. litt. 1 preface 1 (Mynors, Institutiones, 3; trans. TTH 42:105): “They say that such a system existed for a long time at Alexandria and that the Hebrews are now using it enthusiastically in Nisibis, a city of Syria." On Cassiodorus's interest in the School of Nisibis, see also O'Donnell, Cassiodorus, 133; Robert Macina, 
In the absence of other relevant information, the question of Paul the Persian's school seems to stop here. However, it is useful to examine Junillus and Cassiodorus's circle, especially the Roman and Northern African delegates coming or summoned to Constantinople in the 540s and 550s in the context of the Three Chapters Controversy. After the publication in $544 / 545$ of an edict condemning the teaching and some writings of Theodore of Mopsuestia, Theodoret of Cyrus, and Ibas of Edessa, the debate implicated important figures of the western church, who became the main defenders of the incriminated chapters. Their attitude was determined by a very simple argument: if the fathers gathered in Chalcedon had accepted Theodoret and Ibas as Orthodox, the recent imperial condemnation of the Three Chapters also called into question other decisions made by this council. Fighting for the Chalcedonian decisions, the opponents thereby indirectly became defenders of the Antiochian theology. ${ }^{69}$ In this controversy, the position of Junillus and Cassiodorus can hardly be detectednot surprising, given their social position. ${ }^{70}$ However, the absence of any reference to the council of 553 in Cassiodorus's works and his discreet support of Chalcedon, where the fathers "decided that no one on his own ought to introduce new problems," 71 seem to indicate his rejection of the Three Chapters. ${ }^{72}$

\footnotetext{
“Cassiodore et l'école de Nisibe: Contribution à l'étude de la culture chrétienne orientale à l"aube du Moyen âge," in Mus 95 (1982): 131-66; Gianfranco Fiaccadori, "Cassiodorus and the School of Nisibis," in DOP 39 (1985): 135-37.

69. On the position of the North African church regarding the Three Chapters Controversy, see Wolfgang Pewesin, Imperium, ecclesia universalis, Rom: Der Kampf der afrikanischen Kirche um die Mitte des 6. Jahrhunderts, Geistige Grundlagen römischer Kirchenpolitik, Forschungen zur Kirchen- und Geistesgeschichte 11 (Stuttgart: W. Kohlhammer, 1937); Yves Modéran, "L'Afrique reconquise et les Trois Chapitres," in The Crisis of the Oikoumene: The Three Chapters and the Failed Quest for Unity in the Sixth-Century Mediterranean, ed. Celia M. Chazelle and Catherine Cubitt, Studies in the Early Middle Ages 14 (Turnhout: Brepols, 2007), 39-82; Jonathan Conant, Staying Roman: Conquest and Identity in Africa and the Mediterranean, 439-700, Cambridge Studies in Medieval Life and Thought 4 (Cambridge: Cambridge University Press, 2012), 317-24.

70. On Junillus's attitude regarding the legal politics of Justinian see Michael Maas, "Junillus Africanus' Instituta regularia divinae legis in Its Justinianic Context," in The Sixth Century, End or Beginning?, ed. Pauline Allen and Elizabeth Jeffreys, Byzantina Australiensia 10 (Brisbane: Australian Association of Byzantine Studies, 1996), 131-44, here 143-44; Maas, Exegesis and Empire, 65-71.

71. Cass. Div. litt. 1.11.1 (Mynors, Institutiones, 35; trans. TTH 42:134).

72. On Cassiodorus's christology see O'Donnell, Cassiodorus, 166-72; Giuseppe P. de Simone, Cassiodoro e l'Expositio Psalmorum: Una lettura cristologica dei Salmi (Cosenza: Progetto, 2000), 126-40.
} 
Both Junillus and Cassiodorus were in contact with Primasius of Hadrumetum, a city in the northern African province Byzacena. Junillus dedicated his work to Primasius after the African bishop's first visit to Constantinople, in all likelihood in 542, ${ }^{73}$ while Cassiodorus mentions two of the "blessed" Primasius's books, The Commentary on the Apocalypse and The Effect of Heresy. ${ }^{74}$ It is likely that Cassiodorus and Primasius also met together in Constantinople in the 540s. ${ }^{75}$ Primasius returned to Constantinople in 551, summoned by Justinian following the refusal of the African episcopate to accept the first condemnation of the Three Chapters (Iudicatum) signed by Pope Vigilius in $548 .{ }^{76}$ Primasius became one of the main opponents of the Three Chapters and the sole African bishop who signed, along with Pope Vigilius, the first Constitutum addressed to bishops gathered in council in Constantinople in 553. ${ }^{77}$ Finally, in 554, he accepted the conciliar decisions and assumed the primacy of Byzacena. ${ }^{78}$

Cassiodorus also cites and praises Facundus of Hermiane, ${ }^{79}$ already mentioned. Facundus arrived in Constantinople in 547, where he began to write his Defense of the Three Chapters, published in $550 .{ }^{80}$ In turn, Facundus praised in his work the "venerable" Roman deacons Pelagius and Anatolius as well as the deacon and monk Ferrandus of Carthage, of "admirable memory," for their fight for the true faith. ${ }^{81}$

The deacon Pelagius, ${ }^{82}$ apocrisiarius to Constantinople from 536 to 543, was one of the architects of the condemnation of Origen by Justinian in 543. He returned to Constantinople in 551 and supported Pope Vigilius

73. Iunil. Inst. preface (Kihn and Maas, Exegesis and Empire, 118-19).

74. Cass. Psal. 118.2 (ed. Marcus Adriaen, Magni Aurelii Cassiodori Expositio Psalmorum, 2 vols., CCSL 97-98 [Turnhout: Brepols, 1958], here CCSL 98:1060; trans. Patrick G. Walsh, 3 vols., ACW 51-53 [New York, 1990-91], here ACW 53:176); Cass. Psal. 138 (CCSL 98:1255; trans. ACW 53:385 and 516n59); Cass. Div. litt. 1.9.4 (Mynors, Institutiones, 33; trans. TTH 42:132).

75. See Conant, Staying Roman, 344.

76. Vict.-Ton. Chronicon 143 (ed. Carmen Cardelle de Hartmann, Victor Tunnunensis Chronicon cum reliquiis ex Consularibus Caesarangustanis et Iohannes Biclarensis Chronicon, CCSL 173A [Turnhout: Brepols, 2001], 1-55, here 47).

77. Vigilius, First Constitutum (ed. Otto Günther, Epistulae imperatorum pontificum aliorum inde ab a. CCCLXVII usque ad a. DLIII datae Avellana quae dicitur collection, 2 vols., CSEL 35 [Vienna: F. Tempsky, 1895-98], 1:230-320, here 319; trans. Richard Price, The Acts of the Council of Constantinople of 553, 2 vols., TTH 51 [Liverpool: Liverpool University Press, 2009], 2:145-213, here 212).

78. Vict.-Ton. Chronicon 145 (CCSL 173A:47-48).

79. Cass. Psal. 138 (CCSL 98:1255; trans. ACW 53:385).

80. Vict.-Ton. Chronicon 141-42 (CCSL 173A:46).

81. Facundus, Def. 4.3.7-9 (CCL 90A:122-23; trans. SC 478:191).

82. See PCBE 2:1710-16 (Pelagius 3). 
in his opposition to the religious politics of Justinian. In 554, he wrote a Defense of the Three Chapters, principally inspired by the work of Facundus. ${ }^{83}$ But like Primasius of Hadrumetum, Pelagius would later change his opinion and, in order to become pope after the death of Vigilius (555), he ultimately accepted the condemnation of the Three Chapters. ${ }^{84}$

The deacon and monk Ferrandus of Carthage, ${ }^{85}$ a disciple of bishop Fulgentius of Ruspe, ${ }^{86}$ wrote a famous letter to the Roman deacons Pelagius and Anatolius in 546 in defense of the Three Chapters. ${ }^{87}$ There is also a small letter by Ferrandus addressed to Junillus, ${ }^{88}$ who was part of Fulgentius's circle. ${ }^{89}$ Ferrandus wrote to the priest and abbot Felix, a friend of the same Fulgentius. ${ }^{90}$ A manuscript belonging to Fulgentius and then Ferrandus containing Hilary of Poitiers's Trinitarian writings later arrived in Cassiodorus's monastic library of Vivarium. ${ }^{91}$

However, this Felix could be identified as the abbot Felix of Gillium, mentioned by Pope Vigilius ${ }^{92}$ and Victor of Tunnuna ${ }^{93}$ as one of the chief instigators of the African opposition in Constantinople. In Vigilius's description, Felix had scattered with levity and changeableness the community of his

83. Pelag.-Diac. Def. (ed. Robert Devreese, Pelagii Diaconi Ecclesiae Romanae in defensione Trium Capitulorum, ST 57 [Vatican: Libreria Vaticana, 1932]). On this influence, see Luise Abramowski, "Die Zitate in der Schrift 'In Defensione Trium Capitulorum' des Römischen Diakons Pelagius," in VC 10.1 (1956): 160-93.

84. Ps.-Facundus, Ep. 7 (ed. Jean-Marie Clément and Roel Vander Plaetse, Facundi Episcopi Ecclesiae Hermianensis opera omnia, CCL 90A [Turnhout: Brepols, 1974], 420; trans. Aimé Solignac, Facundus d'Hermiane, Épître de la foi catholique, SC 499 [Paris: Éditions du Cerf, 2006], 289).

85. Prosopographie chrétienne du Bas-Empire, Vol. 1: Prosopographie de l'Afrique chrétienne (303-533), ed. André Mandouze (Paris: Éditions du Centre National de la Recherche Scientifique, 1982), 446-50.

86. PCBE 1:507-13.

87. Ferrand, Ep. 6 (PL 67:921-28; trans. Price, Acts, 1:112-21).

88. Ferrand. Ep. 8 (ed. August Reifferscheid, Anecdota Casinensia [Breslau: Typis officinae Universitatis, 1871], 7).

89. Fulg.-R. Ep. 7.2 (ed. Jean Fraipont, Sancti Fulgentii Episcopi Ruspensis opera, 2 vols., CCSL 91-91A [Turnhout: Brepols, 1968], 245; trans. Daniel Bachelet, Fulgence de Ruspe, Lettres ascétiques et morales, SC 487 [Paris: Éditions du Cerf, 2004], 259).

90. Ferrand. Ep. 5 (Reifferscheid, Anecdota Casinensia, 5); PCBE 1:440 (Felix 89). See also Susan T. Stevens, “The Circle of Bishop Fulgentius," in Traditio 38 (1982): 327-41, here 337.

91. Cf. Conant, Staying Roman, 344 and n179.

92. Cf. Vig. Ep. Rust. 23 (ACO 4.1:188-94, here 194; trans. Price, Acts, 2:8190, here 87). On the localization of Gillium, see Alfred-Louis Delattre, "Fouilles de Carthage, localisation du monastère Gilllitanus," in Comptes rendus des séances de l'Académie des Inscriptions et Belles-Lettres 43.1 (1899): 16-19.

93. Vict.-Ton. Chronicon 147 (CCSL 173A:49). 
monastery in various places, an account that aligns with the portrait of Felix, the friend of Fulgentius. Felix was exiled with the deacon Rusticus in Egypt, where he died in all likelihood in 555. ${ }^{94}$

Finally, Rusticus was among those who opposed the pope's Indicatum of 548. In his letter of condemnation addressed to Rusticus and Sebastian, Vigilius mentions that he had asked Cassiodorus (religiosum uirum item filium nostrum Senatorem) to convince Rusticus of his fault. ${ }^{95}$ Deposed and exiled in Egypt with Felix, ${ }^{96}$ Rusticus returned to Constantinople before 564 and worked to collect acts, documents, and letters regarding the theological controversy, generally to support his Chalcedonian views.

Looking at all these defenders of Chalcedon in contact with Junillus and Cassiodorus, including Primasius, Facundus, Pelagius, Ferrandus, Felix, and Rusticus, it must be noted that some were well connected with the monastery of the Akoimetai. We have already mentioned above the cases of Facundus and Rusticus, who worked in the Akoimete library. According to Victor of Tunnuna, Primasius was also interned in this monastery in 551. ${ }^{97}$ This connection between the Akoimetai and the Latins was surely favored by two aspects. First, the monks knew and utilized the language of their visitors. During the Acacian schism and the Theopaschite controversy, the delegees of the Akoimetai often went to Rome and sustained their position, a fact that supposes a good knowledge of Latin. Second, regarding the Three Chapters, the monks and the Latins fought for the same theological views. It, therefore, becomes clear that in the 540s and 550 s, the monastery of the Akoimetai played a key role in grouping some Latin clerics, monks, and officials animated by the same christological convictions. Junillus and Cassiodorus were among them.

In the case of Cassiodorus, his interest in both monastic life and sacred learning is another argument for this connection with the Sleepless ones. Like Primasius, Facundus, and Rusticus, we have all the reasons to think that Cassiodorus knew the monastery of the Akoimetai and its library. It also seems that some of Cassiodorus's regulations for his monastery of Vivarium were inspired by the customs of the Sleepless monks. One can remark that the founder provided his monastery with a solar clock for day and a water clock for night furnished so that the monks might be always called "to carry on the divine work as though by the sound of trumpets." 98

94. Vict.-Ton. Chronicon 158 (CCSL 173A:51).

95. Vig. Ep. Rust. 18 (ACO 4.1:193; trans. Price, Acts, 2:88).

96. Vict.-Ton. Chronicon 147 (CCSL 173A:49).

97. Vict.-Ton. Chronicon 145 (CCSL 173A:46).

98. Cass. Div. litt. 1.30.5 (Mynors, Institutiones, 78; trans. TTH 42:165). 
Night activity was therefore common at Vivarium, the monks also having self-fueling mechanical lights "made for study at night" at their disposal. ${ }^{99}$ It is also worth noting that in the monastery there were baths, permanently alimented by clear streams, constructed "to benefit the afflictions of the body." 100 Cassiodorus's monks were advised to take regular baths, without attaching themselves to the pleasures of the present world, but rather transferring their desires to the future one. This facility was not usual in contemporary Latin monasteries, ${ }^{101}$ while in Constantinople the only monastic bath attested in both this period and a long time afterward, is that of the Akoimetai, criticized for their "excessive use of bath and bodily refreshments." ${ }^{102}$ In fact, the most likely place in the Constantinople area to have inspired Cassiodorus was the monastery of the Sleepless ones.

However, this wasn't the only instance of the influence of the Akoimetai on western monasticism. Their ascetic model had been adopted in 515 in Burgundy at the monastery of Agaune, rebuilt by the ruler Sigismund and bishop Avitus of Vienne. There the incessant prayer, laus perennis, became common practice. ${ }^{103}$ The date of this foundation perfectly accords

99. Cass. Div. litt. 1.30.4 (Mynors, Institutiones, 77; trans. TTH 42:165).

100. Cass. Div. litt. 1.29.1 (Mynors, Institutiones, 73; trans. TTH 42:162).

101. Aug. Ep. 211.13 (ed. Alois Goldbacher, S. Aureli Augustini Hipponiensis Episcopi epistulae, 5 vols., CSEL 34/1-2, 44, and 57-58 [Vienna: F. Tempsky, 18951923], here CSEL 57:367; trans. John G. Cunningham, The Confessions and Letters of St. Augustine, NPNF 1 [1st series] [Buffalo: Christian Literature Co, 1886; repr. Grand Rapids: Christian Classics Ethereal Library, 1994], 567); Ben. Reg. 36.8 (ed. and trans. Adalbert de Vogüé and Jean Neufville, La Règle de Saint Benoît, 6 vols., SC 181-86 [Paris: Éditions du Cerf, 1971-72], here SC 182:570-71).

102. Ps-Zach. Chr. 7.7a and 7.8b (CSCO 84:39 and 42; trans. TTH 55:251-52 and 256-57). Cf. Albrecht Berger, Das Bad in der byzantinischen Zeit, Miscellanea Byzantina Monacensia 27 (Munich: Institut für Byzantinistik und Neugriechische Philologie, 1982), 34-45; Fikret Yegül, "The Baths of Constantinople: An Urban Symbol in a Changing World," in Archaeology and History in Roman, Medieval and Post-Medieval Greece: Studies on Method and Meaning in Honor of Timothy E. Gregory, ed. William R. Caraher, Linda Jones Hall, and R. Scott Moore (Aldershot: Ashgate, 2008), 169-95; James Crow, "Water and Late Antique Constantinople: 'It Would Be Abominable for the Inhabitants of This Beautiful City to Be Compelled to Purchase Water," in Two Romes: Rome and Constantinople in Late Antiquity, ed. Lucy Grig and Gavin Kelly, Oxford Studies in Late Antiquity (Oxford: Oxford University Press, 2012), 116-36. On baths and bathing in Christian contexts see also Fikret Yegül, Baths and Bathing in Classical Antiquity (New York: The Architectural History Foundation, 1982), 314-20 and 324.

103. Alcim. Hom. 25 (ed. Rudolf Peiper, Alcini Aviti opera, MGH AA 6.2 [Berlin: Weidmann, 1883], 145-46; trans. Danuta Shanzer and Ian Wood, Avitus of Vienne, Letters and Selected Prose, TTH 38 [Liverpool: Liverpool University Press, 2002], 377-81). 
with an important epistolary exchange between the founders and Emperor Anastasius, the patriarch Timotheus, and the imperial court of Constantinople, mediated by, among others, the priest Laurentius. ${ }^{104}$ Information about the Akoimetai's monastic style of life could have thereby reached the Burgundian milieu. It seems that the connections between Byzantium and Burgundy were even more numerous in this period, as Ian Wood has recently pointed out. ${ }^{105}$ Barbara Rosenwein has suggested that what the Burgundian delegees learned from the Sleepless ones in the early sixth century "had less to do with the monks' liturgical round than with their expertise at street demonstrations, ${ }^{106}$ but this point of view seems inconsistent with the significant Latin presence in the library of the Akoimetai a few decades later.

Following this approach, Cassiodorus was influenced in Constantinople by two models: the school of Paul the Persian and the monastery of the Akoimetai. This fact places the two models in the same network and raises the question of the mutual influence between them. What was the nature of this connection between Paul the Persian and the Sleepless monks? Were the already-mentioned links between Persia and the Akoimetai strong enough that a Persian from Nisibis coming to Constantinople in the sixth century could be received or helped by these monks? In our opinion, the answer is related to an aspect of the Akoimetai's daily life, not yet discussed: the educational process of the future monks. The question is complex. When and where were the novices instructed? Was there a monastic school for them? Who were their teachers? We have no relevant data about these aspects, but the number, intellectual level, library, and influence of the Akoimetai are solid arguments for the existence of such a school. Two other aspects sustain the idea of this monastic school and reveal its role as a meeting point between Paul the Persian and the Sleepless ones.

On the one hand, it's worth observing that the educational institution

104. Alcim. Ep. 9, 46A, 47, and 48 (ed. Peiper, Alcini Aviti opera, 43-44 and 76-78; trans. Shanzer and Wood, Avitus of Vienne, Letters and Selected Prose, 134-53).

105. Ian Wood, "The Burgundians and Byzantium," in Western Perspectives on the Mediterranean: Cultural Transfer in Late Antiquity and the Early Middle Ages, ed. Andreas Fischer and Ian Wood (London: Bloomsbury, 2014), 1-15. See also Philippe Bernard, "La laus perennis d'Agaune dans la Gaule de l'Antiquité tardive: État des questions et éléments d'un bilan," in Sine musica nulla disciplina: Studi in onore di Giulio Cattin, ed. Franco Bernabei and Antonio Lovato (Padua: Il Poligrafo, 2006), 39-69.

106. Barbara H. Rosenwein, "Perennial Prayer at Agaune," in Monks and Nuns, Saints and Outcasts: Religion in Medieval Society, Essays in Honor of Lester K. Little, ed. Sharon A. Farmer and Barbara H. Rosenwein (Ithaca: Cornell University Press, 2000), 37-56. 
founded by Cassiodorus was not a secular nor ecclesiastical school, but a monastic one. ${ }^{107}$ The main aim of Cassiodorus's rules was the permanent education of his monks, ${ }^{108}$ by integration, it's true, of secular learning in the educational system, ${ }^{109}$ but he mentioned neither future clergymen nor laypeople among his students. The Explanation of the Psalms, written by Cassiodorus in Constantinople, was also taught as an instrument offered to the monks for both common prayer and private contemplation. ${ }^{110}$ It cannot be excluded that during his stay in the capital, Cassiodorus had seen a school like this in or in connection with the monastery of the Sleepless ones.

On the other hand, a monastic school or a school linked to a monastery seems to be the ideal place in Constantinople where Paul could have demonstrated his abilities as a teacher and disseminated his knowledge. If we turn again to Persia, we are impressed by the powerful connection existing between monastery and school especially before Abraham of Kashar's monastic reform. Florence Jullien has convincingly argued that the communities founded by Abdā, already mentioned, and his disciples in fifth-century Persia, functioned as monastic schools. ${ }^{111}$ Prayer and theological study were closely joined. At the end of the instruction period, students could choose either a secular ecclesial mission or monastic life within the same convent. ${ }^{112}$ Moreover, the rule of Abdā's influence was not limited; rather, it became the most widespread monastic pattern until the sixth century. According to the Chronicle of Seert, Cyrus of Edessa, another disciple of Mar Aba, founded such a monastery school in Hirtā, where the great catholicos was also buried. ${ }^{113}$ Regarding the School of Nisibis, in recent years, its ascetic dimension has been better highlighted. Arthur Vööbus and Adam Becker have noted that the teachers and students

107. On this topic see Pierre Riché, Éducation et culture dans l'Occident barbare, VIe-VIIIe siècles (Paris: Éditions du Seuil, 1962), 204-12; O’Donnell, Cassiodorus, 177-222.

108. Cass. Div. litt. 1.32.4 (Mynors, Institutiones, 80-81; trans. TTH 42:167).

109. Cass. Div. litt. 2, concl. 3 (Mynors, Institutiones, 159; trans. TTH 42:230); Cass. Psal. preface 15 (CCSL 97:19-21; trans. ACW 51:38-40).

110. See O’Donnell, Cassiodorus, 172-76; Gerda Heydemann, “The Orator as Exegete: Cassiodorus as a Reader of the Psalms," in Reading the Bible in the Middle Ages, ed. Jinty Nelson and Damien Kempf, Studies in Early Medieval History (London: Bloomsbury, 2015), 19-42; Derek A. Olsen, The Honey of Souls: Cassiodorus and the Interpretation of the Psalms in the Early Medieval West (Collegeville: Liturgical Press, 2017), 303.

111. Florence Jullien, Le monachisme en Perse: La réforme d'Abraham le Grand, père des moines de l'Orient, CSCO 622 (Leuven: Peeters, 2008), 94-99.

112. Chr. Seert 1.60 (PO 5:307-8).

113. Chr. Seert 1.29-30 (PO 7:170-71). 
of this school had to live as brothers within the community, share food and common spaces, and pray and learn the Scriptures together. Their life may be regarded as "a form of monasticism more broadly defined." 114 This strong link between monastery and school remained visible in Persian monasticism for a long period. ${ }^{115}$

All these aspects shed more light on the relationship between Paul the Persian and the Akoimetai. In fact, as in the case of Leontius of Byzantium's treatise, the only documented place in sixth-century Constantinople where Paul could simultaneously pursue his educational activity, conserve the Persian monastic school model, implement the School of Nisibis's curriculum, gain the Latin defenders of Chalcedon's admiration, and establish links with Cassiodorus's monastic source of inspiration was a school organized in connection with the Akoimetai's monastery. It is not necessary to claim that Paul the Persian was a teacher in the monastic school of the Sleepless ones, even though this too is possible. It's easier to see this Paul's school as only related to the monastery. It could even have been situated in the city, in one of the dependencies or other monasteries of the Akoimetai's network, while keeping the link with the Sleepless ones and their circle, sharing their christological views, and using their library. Paul's reputation impressed Junillus in the 530s and convinced Cassiodorus to take the path to the Akoimetai in the 540s. However, in the context of the conflict between the monks and the imperial power, neither Junillus nor Cassiodorus ever mentions the Sleepless ones, but they prefer to indicate only the more neutral school of Nisibis and its educational process.

\section{CONCLUSION}

The arguments presented above prove that in the fifth and sixth centuries, the monastery of the Akoimetai was well connected with both the Syriac East and the Latin world. Founded as a monastery with a strong liturgical vocation, it also played an important role in the christological

114. Vööbus, History of the School of Nisibis, 109-15 and 269-74; Adam H. Becker, Fear of God and the Beginning of Wisdom: The School of Nisibis and the Development of Scholastic Culture in Late Antique Mesopotamia, Divinations: Rereading Late Ancient Religion (Philadelphia: University of Pennsylvania Press, 2006), 77-87 and 172-75.

115. On this topic see Françoise Briquel Chatonnet, "La religion comme enseignement: Les écoles dans la tradition historique et culturelle de l'Église syroorientale," in Comptes rendus des séances de l'Académie des Inscriptions et Belles Lettres 152.1 (2008): 59-76, here 64-65; Becker, Fear of God, 160-63 and 169-75. 
debates of the time. Its intellectual circle, theological work, and library influenced and inspired in a remarkable way the ecclesiastical and monastic life in Constantinople and beyond. A cross-reading of Greek, Syriac, and Latin sources reveals contacts and exchanges existing between monks and important theologians and churchmen of the time. Two names must be added to the circle of persons gravitating, even for a short period, around the monastery of the Akoimetai: Mar Aba and Paul the Persian.

Mar Aba visited the library of the Sleepless ones, where he found, among other books of interest, the Greek text of Theodore of Mopsuestia's anaphora. This fact, indirectly confirmed by Leontius of Byzantium, shows on the one hand that the Akoimetai served as a landmark for the Persian theologians or ascetics coming to Constantinople. On the other hand, it indicates the role of this monastery in the first religious formation of Leontius.

Paul the Persian also used such a network and organized his theological school in connection with the monastery of the Akoimetai. He attracted the interest of several learned Latins including Junillus and Cassiodorus. It's surprising to constate a close resemblance between the monastic school criticized by Leontius of Byzantium and the theological school praised by Junillus. Did they describe the same school? Or rather were two schools included in the same network?

From our point of view, both Mar Aba and Paul the Persian knew the Syrian background of the Akoimetai well and utilized it to pursue their interests: either to export to Persia old texts and new customs or to disseminate their knowledge in Constantinople. Former members of the school of Nisibis's community, they traveled to the capital of the Roman world with similar cultural and educational baggage and were animated by similar goals, even if their subsequent experience would prove to be different. Did they see each other in Constantinople? The question remains open, but in our opinion, their meeting was more than possible.

Daniel Oltean is a Postdoctoral Fellow of the Research FoundationFlanders at the Institute of Byzantine and Early Christian Studies, KU Leuven 
